
Not for reproduction, distribution or commercial use.

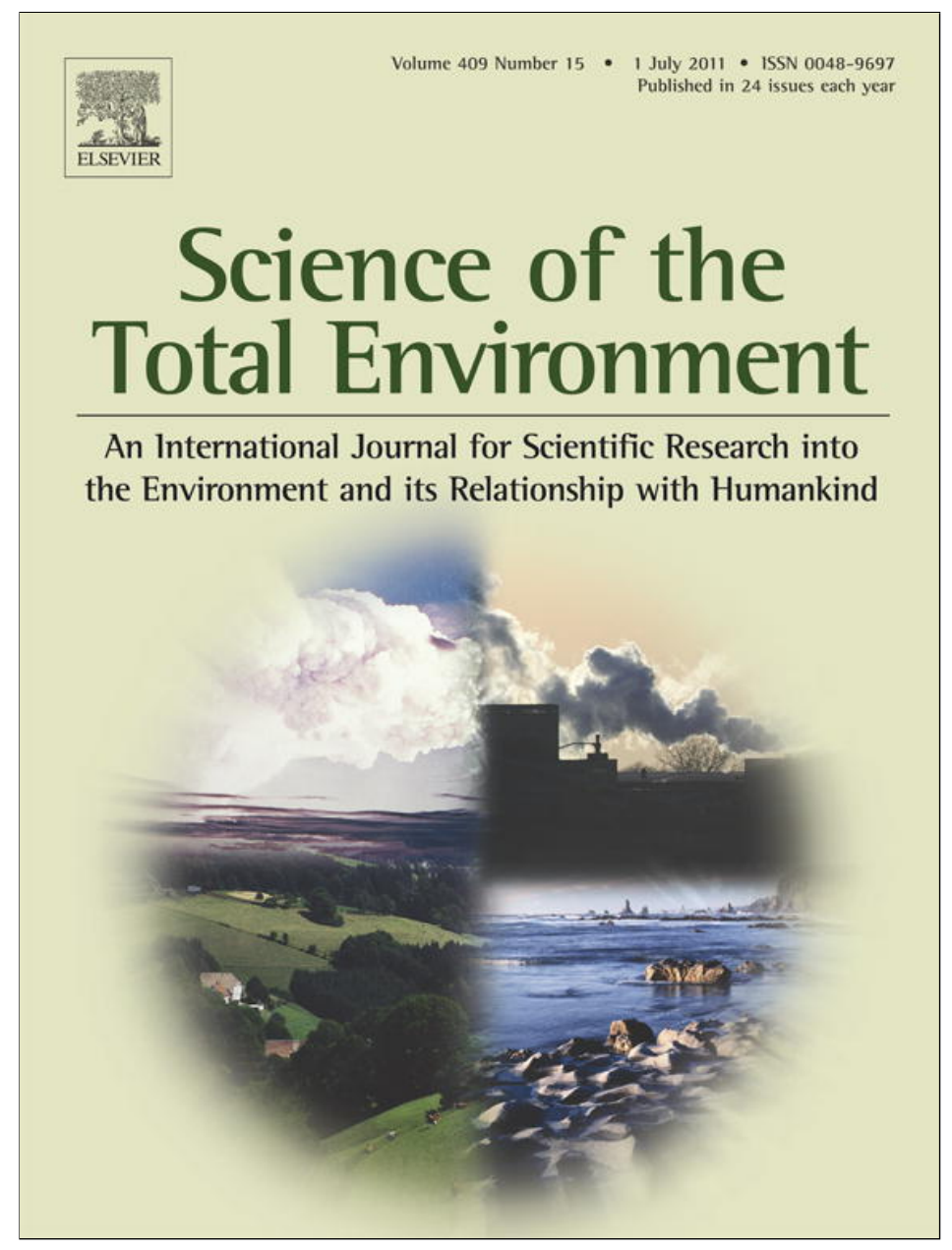

This article appeared in a journal published by Elsevier. The attached copy is furnished to the author for internal non-commercial research and education use, including for instruction at the authors institution and sharing with colleagues.

Other uses, including reproduction and distribution, or selling or licensing copies, or posting to personal, institutional or third party websites are prohibited.

In most cases authors are permitted to post their version of the article (e.g. in Word or Tex form) to their personal website or institutional repository. Authors requiring further information regarding Elsevier's archiving and manuscript policies are encouraged to visit:

http://www.elsevier.com/copyright 


\title{
Persistent organochlorine compounds in fetal and maternal tissues: Evaluation of their potential influence on several indicators of fetal growth and health
}

\author{
Roberto Bergonzi ${ }^{\mathrm{a}, *}$, Giuseppe De Palma ${ }^{\mathrm{a}}$, Cristina Specchia ${ }^{\mathrm{b}}$, Mariadaniela Dinolfo ${ }^{\mathrm{b}}$, Cesare Tomasi ${ }^{\mathrm{a}}$, \\ Tiziana Frusca ${ }^{\mathrm{b}}$, Pietro Apostoli ${ }^{\text {a }}$ \\ ${ }^{a}$ Department of Experimental and Applied Medicine, Section of Occupational Health and Industrial Hygiene, University of Brescia, Viale Europa 11, 25123 Brescia, Italy \\ ${ }^{\mathrm{b}}$ Materno-Fetal Medicine Department of Obstetrics and Gynecology, University of Brescia, Italy
}

\section{A R T I C L E I N F O}

\section{Article history:}

Received 8 October 2010

Received in revised form 7 April 2011

Accepted 14 April 2011

\section{Keywords:}

Persistent organic pollutants

Prenatal exposure

Umbilical cord serum

Birth weight

Length of gestation

\begin{abstract}
A B S T R A C T
Some organochlorine compounds, such as polychlorinated biphenyls (PCBs), have a tendency to bioaccumulate in humans and predators at the top of the food chain. We have recently confirmed the transplacental transfer of these compounds and the present study has been designed on the same material with the aim of investigating their potential health effects on newborns from 70 pregnant women, resident in a Northern Italy industrial town. Organochlorine compounds [namely, p,p'-dichlorodiphenyltrichloroethane ( $\mathrm{p}, \mathrm{p}^{\prime}$-DDT), $\mathrm{p}, \mathrm{p}^{\prime}$-dichlorodiphenyldichloroethene ( $\mathrm{p}, \mathrm{p}^{\prime}$-DDE), hexachlorobenzene (HCB), and PCBs] have been analyzed both in cord and maternal serum, placenta, and maternal subcutaneous adipose tissue by GC-MSD. p,p'-DDT levels in the adipose tissue resulted significantly $(p<0.05)$ related to birth length. Mothers of neonates born by preterm programmed caesarean delivery showed significantly $(p<0.005$ for both) higher serum $\mathrm{p}, \mathrm{p}^{\prime}$-DDE serum concentrations and $\mathrm{p}, \mathrm{p}^{\prime}$-DDT levels in the adipose tissue, as compared to mothers delivering at term.
\end{abstract}

(C) 2011 Elsevier B.V. All rights reserved.

\section{Introduction}

Polychlorinated biphenyls (PCBs), hexachlorobenzene (HCB), p, $\mathrm{p}^{\prime}-$ dichlorodiphenyltrichloroethane (p,p'-DDT) and p,p'-dichlorodiphenyldichloroethene (p,p'-DDE) are organochlorine compounds (OCs) present in the environment due to their intensive use both in agriculture and industry in the past years. As a result of limited rates of environmental degradation and lipophilic properties, OCs have a high tendency to bioaccumulate in humans and predators at the top of the food chain. They have been classified as endocrine disrupting chemicals, given their interaction with several functions of the endocrine system (Brouwer et al., 1999; Damstra et al., 2002).

The transplacental transfer of OCs has been documented a few decades ago (Ando et al., 1986) and prenatal exposure to this class of substances has focused interest on potentially related adverse health effects on fetus development. Several outcomes have been found, including reducing birth weight (Rylander et al., 2000), preterm birth (Longnecker et al., 2001) growth retardation (Siddiqui et al., 2003),

Abbreviations: OCs, organochlorine compounds; PCBs, polychlorinated biphenyls $\mathrm{HCB}$, hexachlorobenzene; $\mathrm{p}, \mathrm{p}^{\prime}$-DDT, $\mathrm{p}, \mathrm{p}^{\prime}$-dichlorodiphenyltrichloroethane; $\mathrm{p}, \mathrm{p}^{\prime}$-DDE, $\mathrm{p}$ $\mathrm{p}^{\prime}$ - dichlorodiphenyldichloroethylene.

* Corresponding author at: University of Brescia, Institute of Occupational Health and Industrial Hygiene, Viale Europa 11, 25123 Brescia, Italy. Tel.: + 390303995661 ; fax: + 390303996046 .

E-mail address: bergonzi@med.unibs.it (R. Bergonzi). reducing head circumference (Wolff et al., 2007a), fetal loss (Longnecker et al., 2005a), inhibition of mental and motor development (Walkowiak et al., 2001), and effects on cognitive abilities (Patandin et al., 1999). However, negative or weak outcomes have also been published (Rhainds et al., 1999; Jarrell et al., 2005; Longnecker et al., 2005b; Sagiv et al., 2007).

The aim of the present study was to investigate, on a sample of pregnant women living in an Italian highly industrialized urban area, the relationships among OC levels determined in placenta and other maternal-fetal tissues and several indicators of fetal growth and health.

\section{Materials and analytical methods}

\subsection{Study population}

Seventy Caucasian women, resident for more than 15 years in the province of Brescia, Italy (mean age 33.2 years; range 26-42) and undergoing planned caesarean section at the University Hospital of Brescia for either maternal (previous caesarean section, medical conditions or maternal request) or fetal (mostly breech presentation) indications volunteered to participate in the study, performed in the period January-June 2006.

The biological specimens were sampled according to the declaration of Helsinki; all the women provided a written informed consent to the study. 
Clinical records were used to collect the following information about newborn characteristics: birth weight, head circumference, birth length, Apgar score, umbilical arterial blood $\mathrm{pH}$, and gestational age at delivery (date of delivery minus date of last menstrual period).

Delivery was classified as preterm if it occurred before the 37th week of gestation; small for gestational age and small length for gestational age were defined, respectively, as birth weight or birth length below the 10th percentile for gestational age, in both cases according to gender and parity (Bertino et al., 2010).

The information about potential interfering/confounding variables was collected by a physician during a face-to-face interview using a questionnaire. In addition to the pathological history (inquiring in particular about preeclampsia, hypertension and diabetes), we looked for: parity, alcohol intake and cigarette smoking during pregnancy, work history, marital status, height and body mass index, weight gain during pregnancy, placental weight and newborn gender. We investigated also the residence area and the consumption of locally produced food, because of the documented existence of agricultural areas contaminated by PCBs in Brescia (Donato et al., 2006).

Most (83\%) of the recruited women resided in the surroundings of Brescia; eight of them resided for at least 15 years in very highly industrialized municipalities of the province. Although we did not have specific information on OC contamination, these eight women were considered as living in polluted areas outside the town.

Twelve women resided in Brescia, all in an urban area that was previously classified as having the lowest PCB soil concentration (Donato et al., 2006).

Twenty-six enrolled women consumed locally produced food; only one of them consumed food produced in a PCB polluted area, named area B (Donato et al., 2006), whereas seven women consumed animal or plant food produced in polluted areas outside the town. No woman received estrogens or progestin hormone therapy during pregnancy.

\subsection{Analytical procedure}

OCs were measured in 70 maternal serum samples, 62 cord blood serum samples, 70 placenta samples and 69 adipose tissue samples.

Umbilical cord blood was obtained shortly after caesarean delivery, while maternal blood was collected the day before. Serum was separated by centrifugation and stored at $-30^{\circ} \mathrm{C}$ until analysis. A small piece of about $1 \mathrm{~cm}$ square of subcutaneous adipose tissue from the abdominal wall and a block of $3-4 \mathrm{~cm}$ of placental tissue (near the insertion of umbilical cord) were collected during operative delivery, then stored in aluminum foil and maintained at $-30{ }^{\circ} \mathrm{C}$ until analysis.

Levels of PCB 28, 31, 52, 74, 99, 101, 105, 114, 118, 123, 128, 138, $146,153,156,157,167,170,172,177,180,183,187,189,194,196$, 201, 203, 206, 209, p,p'-DDE, p,p'-DDT and HCB were measured in $1 \mathrm{ml}$ of maternal serum and cord blood serum, 1.4-2.4 grams of placenta and in 50-75 mg of maternal subcutaneous adipose tissue by GC-MSD (gas chromatograph Agilent Technologies $6890 \mathrm{~N}$ equipped with a mass spectrometer detector 5973).

Analyses were subjected to standard quality assurance procedures, by external (for serum) and internal (for all the tissues) quality control programs. Details of analytical method have been reported elsewhere (Bergonzi et al., 2009).

Two method blanks (one of them containing $10 \mu$ of olive oil) were included within each sample batch and were subjected to the entire procedure.

For the determination of organochlorines in serum, control samples purchased from Institute for Occupational, Social and Environmental Medicine-University, Erlangen-Nuremberg, Germany and aliquots of human serum spiked with known amounts of OCs were analyzed.

Moreover, in order to check the between-series precision and recoveries of analytical methods for placenta and adipose tissue, we performed the determination of OCs both in aliquots of fortified olive oil (50 mg each, to simulate the adipose tissue) and in $1.5 \mathrm{gram}$ portions of a minced pool of human placentas, spiked with PCBs, p, $\mathrm{p}^{\prime}-$ DDT, p, $\mathrm{p}^{\prime}$-DDE, and HCB standard solutions.

Percent recoveries were between $88.5 \%-112.4 \%, 86.9 \%-102.0 \%$, and $75.4 \%-105.8 \%$ for serum, adipose tissue and placenta analyses, respectively.

GC degradation of p,p'-DDT to p,p'-DDE was evaluated by repeated analyses of standard solutions in the range $1-25 \mathrm{ng} / \mathrm{ml}$ : a proportional increase of $\mathrm{p}, \mathrm{p}^{\prime}$-DDE peak area with increasing $\mathrm{p}, \mathrm{p}^{\prime}$-DDT levels was observed. However, the magnitude of degradation was so low as to have no implication in our results, as for example, the percentage of samples with p,p'-DDT levels above the LOQ.

Furthermore, the estimated concentration of $\mathrm{p}, \mathrm{p}^{\prime}$-DDE produced from the degradation of $\mathrm{p}, \mathrm{p}^{\prime}$-DDT in the most contaminated adipose tissue sample of our study was well below the limit of quantification, suggesting a nonsignificant interference on the $\mathrm{p}, \mathrm{p}^{\prime}$-DDE results. Finally, having observed the proportionality of the degradation, results do not require corrections to calculate concentrations of p,p '-DDT in samples.

Maternal serum concentrations of persistent organochlorine pollutants were expressed in lipid weight, calculated with the formula described by Phillips et al., after enzymatic determination of total cholesterol (TC) and triglycerides (TG) (Phillips et al., 1989).

\subsection{Statistical analysis}

Statistical analysis was performed using the PASW Statistics 18.0 for Windows ${ }^{\circledR}$ statistical package (IBM SPSS Inc; Chicago, IL, USA). The distribution of continuous variables was examined by the Kolmogorov-Smirnov test. OCs followed a log normal distribution. Both parametric and nonparametric tests were performed to evaluate the correlations between OC levels and either newborn anthropometric measures or potentially interfering variables.

Student's $t$ test for independent samples and Levene's test for equality of variances were conducted on log-transformed data to assess differences between two groups. Correlations among variables were investigated by Spearman's non parametric test.

The Kruskal-Wallis rank test and the Mann-Whitney $U$ test were used to evaluate, respectively, differences in the sample stratified by quartiles, or the 90th percentile and 10th percentile of OC levels.

Both multiple linear and logistic regression analyses were performed, including neonatal characteristics (dichotomized at a cut off of the 90th percentile for logistic regression) as dependent variables. Covariates in the models were: concentrations of OCs in all analyzed tissues, maternal height, pre-pregnancy BMI, prepregnancy weight, maternal weight gain, maternal age, and gestational length. Further covariates (factors in the logistic regression models) included gender, alcohol and smoking habits during pregnancy, diabetes, maternal occupation and marital status. SPSS Neural networks (Multilayer Perceptron technique) were also adopted.

In every case, a two-tailed $p$-value of 0.05 was adopted to refuse the null hypothesis.

\section{Results}

Socio-demographic characteristics of enrolled women are described in Table 1. A minority of participants (about 16\%) was multiparous and most of them were married, as were employed. The majority of women (about 63 and 86\%, respectively) did not smoke or take alcoholic drinks during pregnancy. Four children (5.7\%) were born preterm, 7 (10\%) were small for gestational age, 3 (4.3\%) were born with a small length for gestational age and 1 showed small head circumference for gestational age. Forty-three (61\%) children were males, with a mean birth weight of 3385 grams ( \pm 381$)$, whereas the 
Table 1

Socio-demographic characteristics of enrolled women $(n=70)$.

\begin{tabular}{lllr}
\hline & & No./mean \pm SD & $\%$ \\
\hline Age (years) & & $33.2 \pm 4.0$ & \\
Parity & 1 & 23 & 32.9 \\
& $\geq 2$ & 36 & 51.4 \\
Marital status & Married & 11 & 15.7 \\
& Unmarried & 53 & 75.7 \\
& Missing information & 16 & 22.9 \\
Occupation & Professional & 1 & 1.4 \\
& Clerical, sales, military, & 28 & 17.1 \\
& service & & 40.0 \\
& Laborer & 12 & \\
& Unemployed & 17 & 17.1 \\
Pre-pregnancy BMI & Missing information & 1 & 24.3 \\
(Kg m $^{-2}$ ) & $<19$ & 4 & 1.4 \\
& $19-24$ & 45 & 5.7 \\
Smoking during pregnancy & $\geq 25$ & 20 & 64.3 \\
& Missing information & 1 & 28.6 \\
Alcohol use during & No & 26 & 1.4 \\
pregnancy & Yes & 44 & 37.1 \\
& No & 10 & 62.9 \\
& & 60 & 14.3 \\
& & & 85.7 \\
\hline
\end{tabular}

mean birth weight of females was $3021( \pm 496)$. The mean gestational length was 38.2 weeks ( \pm 0.6 , range 36.4-39.4). As expected, the birth weight was higher in newborns from diabetic mothers $(n=5$; medians of $4030 \mathrm{~g}$ vs $3250 \mathrm{~g}, p<0.05$ ).

\subsection{Organochlorine levels}

Distribution of OC levels in both maternal and fetal tissues and their correlations confirming the transplacental transfer of these compounds, have been already reported (Bergonzi et al., 2009). In four cases, the cord blood samples could not be tested for HCB levels. The highest OC levels were represented by the sum of $\mathrm{PCB}$ congeners ( $\mathrm{P} P \mathrm{PCBs}$ ), followed by p,p '-DDE and $\mathrm{HCB}$; as expected, the highest $\mathrm{OC}$ concentrations were determined in the maternal adipose tissue. Only one placenta and four maternal serum samples contained detectable amounts of p,p'-DDT, that could, instead, be determined in 64 adipose tissue samples with a geometric mean of $7.6 \mathrm{ng} / \mathrm{g}$ lipids (range: $<\mathrm{LOQ}-55 \mathrm{ng} / \mathrm{g}$ lipids).

\subsection{Correlations of organochlorines with maternal characteristics}

We have already reported that the concentrations of $\Sigma$ PCBs, $\mathrm{p}, \mathrm{p}^{\prime}-$ DDE and HCB in cord and maternal serum, as well as those in placenta and adipose tissue were positively and significantly correlated with maternal age (Bergonzi et al., 2009).

In the adipose tissue, $\mathrm{p}, \mathrm{p}^{\prime}$-DDT, p, $\mathrm{p}^{\prime}$-DDE and HCB concentrations were positively related with both the pre-pregnancy maternal weight (Spearman's rhos $=0.422,0.305$ and 0.261 , respectively; $p<0.001$ for p-p'-DDT and $p<0.05$ for both $\mathrm{p}, \mathrm{p}^{\prime}$-DDE and HCB) and with the prepregnancy maternal BMI (Spearman's rho $=0.445,0.306$ and 0.283 , respectively; $p<0.001$ for $\mathrm{p}, \mathrm{p}^{\prime}-\mathrm{DDT}$ and $p<0.05$ for both $\mathrm{p}, \mathrm{p}^{\prime}$-DDE and HCB). On the other hand, $\Sigma$ PCBs were not significantly associated with either pre-pregnancy weight or BMI (data not shown).

With the exception of p, $\mathrm{p}^{\prime}$-DDT, the OC levels in maternal tissues were negatively related with the maternal weight gain during pregnancy (Spearman's rhos ranging from -0.26 to $-0.45 ; p<0.01$ for $\Sigma$ PCBs, $p<0.05$ for $\mathrm{HCB}, p<0.001$ for $\mathrm{p}, \mathrm{p}^{\prime}$-DDE).

Placental HCB levels were significantly affected by alcohol drinking during pregnancy (geometric means: $23 \mathrm{ng} / \mathrm{g}$ lipids in drinkers vs $21 \mathrm{ng} / \mathrm{g}$ lipids in non-drinkers, $p<0.01$ ), whereas $\mathrm{p}, \mathrm{p}^{\prime}$-DDE and HCB levels in the adipose tissue were influenced by local food consumption (geometric means consumers vs non consumers: 262 vs $213 \mathrm{ng} / \mathrm{g}$ lipids for p,p'-DDE, 27 vs $28 \mathrm{ng} / \mathrm{g}$ lipids for HCB; $p<0.05$ for both). Smoking habits, residence in the highly industrialized municipalities, and consumption of food produced in the industrialized areas outside the town failed to affect OC levels in investigated samples.

\subsection{Correlations of organochlorines with newborns' outcomes}

Table 2 shows the results of the Spearman's correlation analysis among OC tissue concentrations and birth outcomes. Two significant correlations were apparent, i.e. a significant negative relationship between placental $\Sigma$ PCBs and birth weight (rho $=-0.239, p<0.05)$ and a positive correlation between p,p'-DDT levels in the adipose tissue and birth length $(r h o=0.289, p<0.05)$. No other significant relationship was found, also after controlling for newborn gender.

As shown in Table 3, in four cases of preterm programmed caesarean delivery, we found higher levels of almost all OC compounds than in newborns at term. A statistical significance was observed for $\mathrm{p}, \mathrm{p}^{\prime}$-DDE levels in maternal serum and for $\mathrm{p}, \mathrm{p}^{\prime}$-DDT concentrations in the adipose tissue ( $p<0.005$ for both). Mothers of newborns with a small length or a small weight for gestational age had lower levels of p, $\mathrm{p}^{\prime}$-DDE, but not at a statistically significant level.

No significant difference in birth weight, head circumference, birth length, Apgar score or arterial cord blood $\mathrm{pH}$ was found in samples stratified by quartiles of OC levels (data not shown).

After classification of samples according to the 90th percentile of OC levels, we found that higher Apgar scores at 5 min were associated with higher concentrations of $\Sigma$ PCBs in placenta (median Apgar scores 10 vs $9, p<0.005$ ), adipose tissue (median Apgar scores 10 vs 9 , $p<0.005$ ), and maternal serum (median Apgar scores 10 vs 9, $p<0.05$ ), as well as with higher levels of $\mathrm{HCB}$ (median Apgar scores 10 vs 9 , $p<0.05$ ) in the adipose tissue. Newborns with placental HCB concentrations lower than the 10th percentile showed arterial cord blood $\mathrm{pH}$ values lower than those found in subjects with higher $\mathrm{HCB}$ concentrations (median 7.27 vs 7.29 , respectively; $p<0.05$ ).

Multiple logistic regression analysis showed no significant effect of OC levels (dichotomized on the 90th percentile of data) on newborns' characteristics. Multiple linear regression analyses showed that birth weight, head circumference, and $\mathrm{pH}$ were not affected by maternal or fetal organochlorines, whereas maternal p,p'-DDT levels in adipose tissue were significantly associated with birth length $(\mathrm{p}<0.01)$. Colinearity between p,p'-DDT and newborn's gender was excluded by specific diagnostic tests. The positive association between $\mathrm{p}, \mathrm{p}^{\prime}$-DDT

Table 2

Spearman's rho coefficients of correlation analysis between organochlorine levels in different tissues and birth outcomes.

\begin{tabular}{|c|c|c|c|c|c|}
\hline Organochlorines & & $\begin{array}{l}\text { Birth } \\
\text { weight }\end{array}$ & $\begin{array}{l}\text { Birth } \\
\text { length }\end{array}$ & $\begin{array}{l}\text { Head } \\
\text { circumference }\end{array}$ & $\begin{array}{l}\text { Cord blood } \\
\text { pH }\end{array}$ \\
\hline \multirow[t]{4}{*}{ PCBs } & Cord serum & -0.12 & -0.11 & -0.20 & 0.04 \\
\hline & $\begin{array}{l}\text { Maternal } \\
\text { serum }\end{array}$ & -0.11 & 0.07 & -0.09 & 0.05 \\
\hline & Placenta & $-0.239^{*}$ & -0.06 & -0.09 & 0.04 \\
\hline & $\begin{array}{l}\text { Adipose } \\
\text { tissue }\end{array}$ & -0.16 & -0.01 & -0.14 & 0.09 \\
\hline \multirow[t]{4}{*}{$\mathrm{HCB}$} & Cord serum & -0.00 & -0.02 & -0.02 & 0.06 \\
\hline & $\begin{array}{l}\text { Maternal } \\
\text { serum }\end{array}$ & -0.11 & 0.08 & 0.04 & 0.23 \\
\hline & Placenta & -0.15 & -0.02 & 0.09 & 0.16 \\
\hline & $\begin{array}{l}\text { Adipose } \\
\text { tissue }\end{array}$ & -0.02 & 0.02 & 0.02 & 0.11 \\
\hline \multirow[t]{4}{*}{$\mathrm{p}, \mathrm{p}^{\prime}-\mathrm{DDE}$} & Cord serum & -0.24 & -0.12 & -0.13 & -0.05 \\
\hline & $\begin{array}{l}\text { Maternal } \\
\text { serum }\end{array}$ & -0.18 & -0.02 & -0.03 & 0.01 \\
\hline & Placenta & -0.23 & -0.04 & 0.04 & 0.01 \\
\hline & $\begin{array}{l}\text { Adipose } \\
\text { tissue }\end{array}$ & -0.17 & 0.02 & -0.03 & -0.02 \\
\hline $\mathrm{p}, \mathrm{p}^{\prime}-\mathrm{DDT}$ & $\begin{array}{l}\text { Adipose } \\
\text { tissue }\end{array}$ & 0.03 & $0.289^{*}$ & 0.18 & -0.02 \\
\hline
\end{tabular}

$p<0.05$. 
Table 3

Geometric mean levels of OCs in different tissues, classified by premature births, small weight and small length for gestational age (no. of samples in parentheses). Data are expressed on either volume (cord serum) or fat (maternal serum, placenta, and adipose tissue) weight basis.

\begin{tabular}{|c|c|c|c|c|c|c|c|}
\hline & & \multicolumn{2}{|c|}{ Preterm birth } & \multicolumn{2}{|c|}{ Small weight for gestational age } & \multicolumn{2}{|c|}{ Small length for gestational age } \\
\hline & & Yes & No & Yes & No & Yes & No \\
\hline \multirow[t]{4}{*}{ PCBs } & Cord serum & $0.36(4)$ & $0.23(58)$ & $0.21(4)$ & $0.23(58)$ & $0.32(1)$ & $0.23(61)$ \\
\hline & Maternal serum & $249(4)$ & $229(66)$ & $210(7)$ & $232(63)$ & $216(3)$ & $231(66)$ \\
\hline & Adipose tissue & $456(4)$ & $406(65)$ & $401(7)$ & $409(62)$ & $464(3)$ & $406(65)$ \\
\hline & Placenta & $146(4)$ & $96(66)$ & $112(7)$ & $97(63)$ & $115(3)$ & $98(66)$ \\
\hline \multirow[t]{4}{*}{$\mathrm{p}, \mathrm{p}^{\prime}-\mathrm{DDE}$} & Cord serum & $0.44(4)$ & $0.24(58)$ & $0.23(4)$ & $0.26(58)$ & $0.18(1)$ & $0.26(61)$ \\
\hline & Maternal serum & $176(4)$ & $124(66) *$ & $96(7)$ & $130(63)$ & $67(3)$ & $130(66)$ \\
\hline & Adipose tissue & $346(4)$ & $224(65)$ & $178(7)$ & $236(62)$ & $132(3)$ & $235(65)$ \\
\hline & Placenta & $131(4)$ & $67(66)$ & $61(7)$ & 70 (63) & $43(3)$ & $71(66)$ \\
\hline \multirow[t]{4}{*}{$\mathrm{HCB}$} & Cord serum & $0.05(4)$ & $0.04(58)$ & $0.04(4)$ & $0.04(58)$ & $0.05(1)$ & $0.04(61)$ \\
\hline & Maternal serum & $19(4)$ & $20(66)$ & $20(7)$ & $20(63)$ & $20(3)$ & $20(66)$ \\
\hline & Adipose tissue & $27(4)$ & $28(65)$ & $27(7)$ & $28(62)$ & $26(3)$ & $28(65)$ \\
\hline & Placenta & $26(4)$ & $21(66)$ & $24(7)$ & $21(63)$ & $20(3)$ & $21(66)$ \\
\hline $\mathrm{p}, \mathrm{p}^{\prime}-\mathrm{DDT}$ & Adipose tissue & $10(4)$ & $7(65)$ * & $6(7)$ & $8(62)$ & $5(3)$ & $8(65)$ \\
\hline
\end{tabular}

concentration in the adipose tissue and birth length was best fitted by the line described by the equation $y=0.067 x+49.268$. A further confirmation of the relationship was obtained by testing the data set by a multilayer perceptron neural network technique of the statistic software.

\section{Discussion}

We have previously demonstrated (Bergonzi et al., 2009) that the maternal tissue levels of $\Sigma$ PCBs, p,p'-DDE, and HCB were positively and significantly related to maternal age, thus confirming both the bio-persistence and the intake through diet of these OCs. Thus, higher fetal exposure to persistent organic pollutants can be considered as a further implication of advanced maternal age.

The levels of p,p'-DDE, HCB, and $\mathrm{Y}$ PCBs in the adipose tissue were negatively associated to maternal weight gain during pregnancy. Alternative possible explanations may be raised for this behavior. Both p, $\mathrm{p}^{\prime}-\mathrm{DDE}$ and HCB were positively correlated with the BMI, that was negatively associated to weight gain during pregnancy $(r=-0.297$, $p<0.05$ ). The progressive reduction of OC exposure levels observed along time may explain why the usually inverse relationship between OC concentrations and BMI predicted by the pharmacokinetic model is reversed from negative to positive (Wolff et al., 2007b).

In the case of $\Sigma$ PCBs, they were negatively correlated with the post-pregnancy weight ( $p<0.05$ for all of tissues). Since this negative association regarded all investigated tissues, a sort of "body dilution" was suspected for these compounds.

As it concerns the relationships between the OC concentrations in maternal/fetal tissues and the investigated birth outcomes, we found a positive association between p,p'-DDT levels in the adipose tissue and birth length and a negative association between the placental $\mathrm{IPCB}$ content and birth weight. The latter, however, was not confirmed by either regression analyses (both linear and logistic) or by multiple comparisons on samples stratified by quartiles of OC levels. Vice versa, the positive $\mathrm{p}, \mathrm{p}^{\prime}$-DDT-birth length relationship was found to be significant both in linear regression statistic approach and in neural network analysis. This result is in agreement with the results of a previous study (Tan et al., 2009) that showed also the association of p,p'-DDT levels in cord blood samples with both newborn head circumference and birth weight.

Premature newborns showed significantly higher concentrations of both p,p'-DDE in maternal serum and p,p'-DDT in the adipose tissue. Ribas-Fito et al. (2002) showed higher cord serum levels of OCs, particularly $\mathrm{p}, \mathrm{p}^{\prime}-\mathrm{DDE}$, in premature newborns, that as in our population sample, were only four (vs 66 controls). Longnecker et al. (2001) found that maternal serum concentrations of p,p'-DDE up to $10 \mu \mathrm{g} / \mathrm{l}$ were associated with increased odds of premature births. Others failed to find effects of $\mathrm{p}, \mathrm{p}^{\prime}$-DDE exposure on gestational length (Berkowitz et al., 1996; Weisskopf et al., 2005). In the present study, only programmed caesarean deliveries were investigated; hence, the evaluation on potential effects of OCs on gestational length is not allowed. We can hypothesize a nonlinear transfer of OCs from mother to fetus during its development, or perhaps, a fluctuation of maternal lipophilic pollutant levels depending on gestational phase.

We failed to find any significant association of OC levels with either small length or weight for gestational age, whereas others found an effect of $\mathrm{HCB}$ cord serum concentrations on small length for gestational age in subjects resident in an HCB polluted area (Ribas-Fito et al., 2002).

Some statistical effects on newborn outcomes were found when percentiles of $\mathrm{OC}$ levels were used to define exposure categories. However, the observed association between placental HCB levels and arterial cord blood $\mathrm{pH}$ cannot be of clinical interest, because the statistical difference between groups of exposure levels was relatively small, with mean values falling within the normality range (Helwig et al., 1996). Similarly, the results involving Apgar score at 5 min appear of limited biological significance, because assigned values were at least 9 .

Maternal alcohol consumption and local food eating during pregnancy apparently influenced OC levels, but the interpretation of these results is hampered by the inconsistent behavior of OCs in different tissues, and by the lack of information about e.g. frequency of consumption.

A more exhaustive study on the influence of consumption of locally produced food regarding 537 subjects aged $20-79$ years living in the same town, found a statistically significant difference in PCB levels between consumers and non-consumers (Donato et al., 2006). Prenatal exposure to cigarette smoking was not related with umbilical cord serum OC concentrations, in agreement with previous findings (Ribas-Fito et al., 2002).

Prenatal exposure to some persistent organic pollutants has been linked to adverse developmental effects in highly exposed human populations. However, epidemiological studies have reached inconsistent conclusions on whether PCBs, p,p'-DDE, p,p'-DDT or HCB are associated with altered anthropometric features in newborns or gestational length. OC levels in maternal serum, maternal milk, cord blood, or extent of fish consumption were used as indicators of prenatal exposure.

Two distinct episodes of acute exposure to PCBs aroused the suspicion that these compounds might cause intrauterine growth retardation. In 1968 , over 1000 people consumed rice bran oil contaminated with PCBs in Japan (the "Yusho" episode). Some newborns of exposed mothers exhibited small size, dark brown pigmentation of skin, and premature eruption of teeth (Yamashita and Hayashi, 1985). Children of women accidentally exposed to large amounts of PCBs in contaminated rice oil in Taiwan in 1979 (the "Yu-Cheng" incident) showed lower birth weight, lower birth length and retarded growth compared to controls (Rogan et al., 1988). However, studies on women occupationally exposed to PCBs and showing blood PCB levels markedly higher than those in the Yusho and Yucheng patients, failed to demonstrate serious adverse effects in 
newborns, indicating that PCBs were not the only causative agents of the Yusho and Yucheng symptoms, but other OCs, such as polychlorinated dibenzofurans (PCDFs), whose presence in the rice oil was subsequently found (Hara, 1985; Taylor et al., 1989; Schantz, 1996).

Among the most cited studies in the scientific literature about the association between $\mathrm{OC}$ prenatal exposure and negative reproductive outcomes in humans, there are those carried out on the Michigan and North Carolina cohorts. In a study involving 242 infants born between 1980 and 1981, whose mothers consumed moderate quantities of contaminated fish from Lake Michigan, the PCB exposure, assessed both by maternal fish consumption and by umbilical cord serum levels, was associated with lower birth weight, smaller head circumference, and shorter gestational age than controls (Fein et al., 1984). However, critical flaws have been noted in the study design, such as in the exposure assessment, selection and comparability of the exposed and control samples (Schell et al., 2001). In addition, 66\% of cord sera PCB levels were below the quantification limit (5 ppb) (Schwartz et al., 1983).

No association between birth weight or head circumference and child's prenatal PCB exposure was found in a cohort of 880 pregnant women selected between 1978 and 1982 from the general population in North Carolina (Rogan et al., 1986). The maternal serum PCB concentration was reported to be higher than that observed in the Michigan cohort (median of $9.06 \mathrm{ng} / \mathrm{mL}$ vs a mean value of $5.5 \mathrm{ng} / \mathrm{mL}$ ). However, the results in the North Carolina cohort were overestimated by a factor of two. So, the exposure levels in the two cohorts were similar, as suggested by Schantz (1996). The analytical technique, relying on packed column GC analysis with a quantification limit of $4 \mathrm{ng} / \mathrm{ml}$, was able to detect PCBs in only $12 \%$ of umbilical cord blood samples, so prenatal exposure was assessed by the analysis of PCBs in maternal milk at birth.

As a possible explanation for conflicting findings, Sagiv et al. (2007) hypothesize a threshold of effects at higher OC concentrations. Studies on highly exposed populations or on biological samples collected several decades ago have, however, obtained inconsistent results (Rylander et al., 1998; Longnecker et al., 2001; Karmaus and Zhu, 2004; Hertz-Picciotto et al., 2005; Farhang et al., 2005; Lamb et al., 2006). Studies on subjects with background exposure levels (assessed by analyses in cord blood serum or plasma or in maternal serum) have shown significant associations between concentrations of OCs and birth weight or birth length, even though with contrasting findings (Patandin et al., 1998; Ribas-Fito et al., 2002; Weisskopf et al., 2005). Often, negative or inconclusive results were reported, supporting the view that the low-level organochlorine exposures may not have a large impact on growth of the developing fetus (Rhainds et al., 1999; Longnecker et al., 2005b; Sagiv et al., 2007).

\section{Conclusion}

The main result of the present study is a positive association between $\mathrm{p}, \mathrm{p}^{\prime}$-DDT levels in maternal adipose tissue and birth length. The birth weight was related with placenta PCB content at correlation analysis, but further multivariate analyses failed to confirm this finding. Both p, $\mathrm{p}^{\prime}$-DDE and $\mathrm{p}, \mathrm{p}^{\prime}$-DDT levels, respectively in maternal serum and adipose tissue, were significantly higher in premature newborns, raising questions on the kinetics of transplacental transfer of OCs. In addition to BMI, maternal pre-pregnancy weight and maternal weight gain should also be included in multivariate models as covariates when the effects of OC exposure on intrauterine growth are evaluated. Despite the considerable number of publications on the argument, the uncertainties regarding growth deficits related to prenatal exposure to OCs seem far to be resolved.

\section{References}

Ando M, Saito H, Wakisaka I. Gas chromatographic and mass spectrometric analysis of polychlorinated biphenyls in human placenta and cord blood. Environ Res 1986;41:14-22.
Bergonzi R, Specchia C, Dinolfo M, Tomasi C, De Palma G, Frusca T, et al. Distribution of persistent organochlorine pollutants in maternal and foetal tissues: data from an Italian polluted urban area. Chemosphere 2009;76:747-54.

Berkowitz GS, Lapinski RH, Wolff MS. The role of DDE and polychlorinated biphenyl levels in preterm birth. Arch Environ Contam Toxicol 1996;30:139-41.

Bertino E, Spada E, Occhi L, Coscia A, Giuliani F, Gagliardi L, et al. Neonatal anthropometric charts: the Italian neonatal study compared with other European studies. J Pediatr Gastroenterol Nutr 2010;51:353-61.

Brouwer A, Longnecker MP, Birnbaum LS, Cogliano J, Kostyniak P, Moore J, et al. Characterization of potential endocrine-related health effects at low-dose levels of exposure to PCBs. Environ Health Perspect 1999;107(Suppl. 4):639-49.

Damstra T, Barlow S, Bergman A, Kavlock R, Van Der Kraak G, editors. Global assessment of the state-of-the-science of endocrine disruptors. WHO/PCS/EDC/02.2. Geneva, Switzerland: World Health Organization, International Programme on Chemical Safety; 2002http://www.who.int/ipcs/publications/endocrine_disruptors/en/. (accessed 03 March 2011).

Donato F, Magoni M, Bergonzi R, Scarcella C, Indelicato A, Carasi S, et al. Exposure to polychlorinated biphenyls in residents near a chemical factory in Italy: the food chain as main source of contamination. Chemosphere 2006;64:1562-72.

Farhang L, Weintraub JM, Petreas M, Eskenazi B, Bhatia R. Association of DDT and DDE with birth weight and length of gestation in the Child Health and Development Studies, 1959-1967. Am J Epidemiol 2005;162:717-25.

Fein GG, Jacobson JL, Jacobson SW, Schwartz PM, Dowler JK. Prenatal exposure to polychlorinated biphenyls: effects on birth size and gestational age. J Pediatr 1984;105:315-20.

Hara I. Health status and PCBs in blood of workers exposed to PCBs and of their children. Environ Health Perspect 1985;59:85-90.

Helwig JT, Parer JT, Kilpatrick SJ, Laros RK. Umbilical cord blood acid-base state: what is normal? Am J Obstet Gynecol 1996;174:1807-14.

Hertz-Picciotto I, Charles MJ, James RA, Keller JA, Willman E, Teplin S. In utero polychlorinated biphenyl exposures in relation to fetal and early childhood growth. Epidemiology 2005;16:648-56.

Jarrell J, Chan S, Hauser R, Hu H. Longitudinal assessment of PCBs and chlorinated pesticides in pregnant women from Western Canada. Environ Health 2005:4:10.

Karmaus W, Zhu X. Maternal concentration of polychlorinated biphenyls and dichlorodiphenyl dichloroethylene and birth weight in Michigan fish eaters: a cohort study. Environ Health 2004;3:1.

Lamb MR, Taylor S, Liu X, Wolff MS, Borrell L, Matte TD, et al. Prenatal exposure to polychlorinated biphenyls and postnatal growth: a structural analysis. Environ Health Perspect 2006;114:779-85.

Longnecker MP, Klebanoff MA, Zhou H, Brock JW. Association between maternal serum concentration of the DDT metabolite DDE and preterm and small-for-gestationalage babies at birth. Lancet 2001;358:110-4.

Longnecker MP, Klebanoff MA, Dunson DB, Guo X, Chen Z, Zhou H, et al. Maternal serum level of the DDT metabolite DDE in relation to fetal loss in previous pregnancies. Environ Res 2005a;97:126-32.

Longnecker MP, Klebanoff MA, Brock JW, Guo X. Maternal levels of polychlorinated biphenyls in relation to preterm and small-for-gestational-age birth. Epidemiology 2005b;16:641-7.

Patandin S, Koopman-Esseboom C, de Ridder MA, Weisglas-Kuperus N, Sauer PJ. Effects of environmental exposure to polychlorinated biphenyls and dioxins on birth size and growth in Dutch children. Pediatr Res 1998;44:538-45.

Patandin S, Lanting CI, Mulder PG, Boersma ER, Sauer PJ, Weisglas-Kuperus N. Effects of environmental exposure to polychlorinated biphenyls and dioxins on cognitive abilities in Dutch children at 42 months of age. J Pediatr 1999;134:33-41.

Phillips DL, Pirkle JL, Burse VW, Bernert JT, Henderson LO, Needham LL. Chlorinated hydrocarbon levels in human serum: effects of fasting and feeding. Arch Environ Contam Toxicol 1989;18:495-500.

Rhainds M, Levallois P, Dewailly E, Ayotte P. Lead, mercury, and organochlorine compound levels in cord blood in Quebec, Canada. Arch Environ Health 1999;54:40-7.

Ribas-Fito N, Sala M, Cardo E, Mazon C, De Muga ME, Verdù A, et al. Association of hexachlorobenzene and other organochlorine compounds with anthropometric measures at birth. Pediatr Res 2002;52:163-7.

Rogan WJ, Gladen BC, McKinney JD, Carreras N, Hardy RN, Thullen J, et al. Neonatal effects of transplacental exposure to PCBs and DDE. J Pediatr 1986;109:335-41.

Rogan WJ, Gladen BC, Hung KL, Koong SL, Shih LY, Taylor JS, et al. Congenital poisoning by polychlorinated biphenyls and their contaminants in Taiwan. Science 1988:241:334-6.

Rylander L, Stromberg U, Dyremark E, Ostman C, Nilsson-Ehle P, Hagmar L. Polychlorinated biphenyls in blood plasma among Swedish female fish consumers in relation to low birth weight. Am J Epidemiol 1998;147:493-502.

Rylander L, Stromberg U, Hagmar L. Lowered birth weight among infants born to women with high intake of fish contaminated with persistent organochlorine compounds. Chemosphere 2000;40:1255-62.

Sagiv SK, Tolbert PE, Altshul LM, Korrick SA. Organochlorine exposures during pregnancy and infant size at birth. Epidemiology 2007;18:120-9.

Schantz SL. Developmental neurotoxicity of PCBs in humans: what do we know and where do we go from here? Neurotoxicol Teratol 1996;18:217-27.

Schell JD, Budinski RA, Wernke MJ. PCBs and neurodevelopmental effects in Michigan children: an evaluation of exposure and dose characterization. Regul Toxicol Pharmacol 2001;33:300-12.

Schwartz PM, Jacobson SW, Fein G, Jacobson JL, Price HA. Lake Michigan fish consumption as a source of polychlorinated biphenyls in human cord serum, maternal serum, and milk. Am J Public Health 1983;73:293-6.

Siddiqui MK, Srivastava S, Srivastava SP, Mehrotra PK, Mathur N, Tandon I. Persistent chlorinated pesticides and intra-uterine foetal growth rerdation: a possible association. Int Arch Occup Environ Health 2003;76:75-80. 
Tan J, Loganath A, Chong YS, Obbard JP. Exposure to persistent organic pollutants in utero and related maternal characteristics on birth outcomes: a multivariate data analysis approach. Chemosphere 2009;74:428-33.

Taylor PR, Stelma JM, Lawrence CE. The relation of polychlorinated biphenyls to birth weight and gestational age in the offspring of occupationally exposed mothers. Am J Epidemiol 1989;129:395-406.

Walkowiak J, Wiener J-A, Fastabend A, Heinzow B, Kramer U, Schmidt E, et al. Environmental exposure to polychlorinated biphenyls and quality of the home environment: effects on psychodevelopment in early childhood. Lancet 2001;358:1602-7.

Weisskopf MG, Anderson HA, Hanrahan LP, Kanarek MS, Falk CM, Steenport DM, et al. Maternal exposure to Great Lakes sport-caught fish and dichlorodiphenyl dichloroethylene, but not polychlorinated biphenyls, is associated with reduced birth weight. Environ Res 2005;97:149-62.

Wolff MS, Engel S, Berkowitz G, Teitelbaum S, Siskind J, Barr DB, et al. Prenatal pesticide and PCB exposures and birth outcomes. Pediatr Res 2007a;61:243-50.

Wolff MS, Anderson HA, Britton JA, Rothman N. Pharmacokinetic variability an modern epidemiology-the example of dichlorodiphenyltrichloroethane, body mass index, and birth cohort. Cancer Epidemiol Biomarkers Prev 2007b;16: 1925-30.

Yamashita F, Hayashi M. Fetal PCB syndrome: clinical features, intrauterine growth retardation and possible alteration in calcium metabolism. Environ Health Perspect 1985;59:41-5. 